\title{
The Role of Q Metric Approach in the Training of Emotional Intelligence Competence among the Employees of the Hospitality Industry, Tamil Nadu- India
}

\author{
Renju Mathai \\ International Business and Management Studies, Stenden University Qatar \\ PO Box 36037, Doha Qatar \\ E-mail: rmathai@stenden.eu.qa
}

Thangaraja Arumugam (Corresponding author)

Department of Management Studies, Manonmaniam Sundaranar University, India

E-mail: Thangaraja.mba@gmail.com

Received: June 02, 2016 Accepted: June 22, 2016 Published: July 15, 2016

doi:10.5296/ijld.v6i2.9547 URL: http://dx.doi.org/10.5296/ ijld.v6i2.9547

\begin{abstract}
It has been observed that training in the hospitality industry becomes a challenge as the employees in this industry have been significantly increased in recent years. Employees are trained to perform well in the organizations while they are also paid to perform in a specific department. It's the combination of experience, calibre, knowledge, skills and abilities that pushes you forward to the particular position to perform in any organization. The hospitality industry expects a high demand in the area of performing and delivering a high quality of service to the guests. Bearing in mind that the hotels needs a constant and regular business to sustain the market. In order to be able to have a strong and healthy competition environment the hotels have come out with a strategy of making and pushing things from the management perspective to deliver and have a high performance by the employees. This paper is to investigate how employees in hotels are encountering emotions with the guests that lead them to underperform in various levels and to see whether training can be applied to increase their performance over time. The main objective of this paper is to investigate the role of Q metric in the training of emotional intelligence competence. The population sample was drawn among the employees of the hospitality industry in Tamilnadu to identify the significance of
\end{abstract}


Q metric. A model was developed by using analysis of moment structure (AMOS). A model is fit to ensure the model for Q metric approach in the training of Emotional intelligence competence among the employees of the hospitality industry, Tamilnadu. Recommendations have been discussed and proposed for future use to any research in this field of academic.

Keywords: Q Metric, Emotional intelligence competence, Hospitality industry

\section{Introduction}

Employees are trained to perform well in the organizations while they are also paid to perform in a specific department. It's the combination of experience, caliber, knowledge, skills and abilities that pushes you forward to the particular position to perform in any organization. The hospitality industry expects a high demand in the area of performing and delivering a high quality of service to the guests. Bearing in mind that the hotels needs a constant and regular business to sustain the market. In order to be able to have a strong and healthy competition environment the hotels have come out with a strategy of making and pushing things from the management perspective to deliver and have a high performance by the employees. By making the employees working hard, it is also seen that the employees are faced with lots of problems when they encounter with the guests while delivering or not delivering the expected service on time. The moment of truth is really tested with the guests by looking into the emotional behavior of the employees. This paper is to investigate how employees in hotels are encountering emotions with the guests that lead them to underperform in various levels and to see whether training can be applied to increase their performance over time.

\section{Objective of the Study}

The aim of this paper is to find out whether $\mathrm{Q}$ metric has any impact on the training for emotional intelligence competence of employees in hospitality industry in Tamilnadu -India are seen as a critical aspect of how employees are underperforming their duties during the service encounters with the guests. It also focuses on how the employee's performances are affected during their work by dealing with the busy schedule of hotel business. The main objective of this research is how $\mathrm{Q}$ metric has impact on the training of the emotional intelligence competence of hospitality industry.

\subsection{Research Question}

The research question is the basic conception of the study. It makes the path for the researcher to travel throughout the study. This study was initiated by the researcher with the research question mentioned below.

What is Q metric and whether it has an impact on training of emotional intelligence competence among employees in hospitality industry, Tamilnadu - India? 


\section{Mll Macrothink

\section{Literature Review}

\subsection{Emotional Intelligence (EI)}

As per Mayer \& Salovey (1997) it's how you see, feel and react towards certain situations that come across and generate as emotions and to demonstrate emotions, to promote in intellectual growth. Emotions are expressed in many ways that is seen in all the individuals. No matter where and which area you are assigned, it comes through various reasons which can be seen in the below frame work. As per the studies highlighted by Akduman et al (2015) Emotional intelligence add the capacity to accomplish and achieve faithful analysis about emotions and the capacity to employ feelings, emotions, and emotional knowledge to augment thought, incorporating particular expertness and suggesting that this distinctive expertness. According to (Goleman, 1995) emotional intelligence is defined to by learning the capabilities which is based on the emotional intelligence that shows an extra ordinary performance in the designated work. People are affected with certain emotions and undergo during their work by facing difficult challenges that is put forth by the management. This is commonly set by knowing through the (MBO) which is management by objectives. Emotional competencies can be job skills that need to be developed and learned to perform well. Emotional intelligence shows that how an employee can perceive or practice the four components Self Awareness; Self-Management; Social-Awareness; Relationship Management. Daniel Goleman (1995) reformulated EI in terms of a theory of organizational and job performance. All these models, however, share a common core of basic concepts including Self-Awareness, Self-Management, Social Awareness, and Relationship Management. The Consortium for Research on Emotional Intelligence in Organizations (www.eiconsortium.org) is a useful website that serves as a resource portal on the topic of emotional intelligence including information on measures, current findings and EI resources. 
Table 1: Emotional Intelligence Competence for Employees

\begin{tabular}{|c|c|c|}
\hline \multirow{2}{*}{\multicolumn{2}{|c|}{$\begin{array}{c}\text { Self } \\
\text { Personal Competence }\end{array}$}} & \multirow{2}{*}{$\begin{array}{l}\text { Other } \\
\text { Social competence }\end{array}$} \\
\hline & & \\
\hline Recognition & $\begin{array}{l}\text { Self-Awareness } \\
\text { \#Emotional self-awareness } \\
\text { \# Accurate self-assessment } \\
\text { \# Self-confidence }\end{array}$ & $\begin{array}{l}\text { Social Awareness } \\
\qquad \text { Empathy } \\
\text { \# Service orientation } \\
\text { \# Organizational awareness }\end{array}$ \\
\hline Regulation & $\begin{array}{l}\text { Self-Management } \\
\text { \& Self-control } \\
\text { \& Trustworthiness } \\
\text { \& Conscientiousness } \\
\text { \& Adaptability } \\
\text { \& Achievement drive } \\
\text { \& Initiative }\end{array}$ & $\begin{array}{l}\text { Relationship Management } \\
\text { \# Developing others } \\
\text { \# Influence } \\
\text { \# Communication } \\
\text { \# Conflict management } \\
\text { \# Leadership } \\
\text { \# Change catalyst } \\
\text { \# Building bonds } \\
\text { \# Teamwork \& collaboration }\end{array}$ \\
\hline
\end{tabular}

Source: (Daniel Goleman 2010)

\subsection{Self-Awareness}

The first component is the self-awareness is the self-awareness what one knows and feels of the activities that he does in his or her day to work. This in turn will have to taken into the consideration of how the employee feels himself. Based on the studies of Kumari (2016) Self-awareness is the ability and the way to understand your own moods and emotions, both in terms of their effect on you, and their effect on your behavior. According to Taylor, Parker, \& Bagby, (1999) self-awareness can be a mirror concepts that reflecting in the working environment and the activities that a person is quite sure of. This can be a deficiency in the working in the particular departments as well.

\subsection{Self-Management}

According to Boyatzis, Goleman, \& Rhee, (2000). The second component of EI, Emotional Self-Management, is the ability to regulate distressing affects like anxiety and anger and to inhibit emotional impulsivity. The other aspect of the self-management is to control or 
redirect disruptive impulses and moods. The propensity to suspend judgement to think before acting is seen by the studies of Deshwal (2016)

\subsection{Social Confidence}

The third aspect of self-awareness is self-confidence which is considered to be one of the strongest factors in determining the level of performance among employees. Based on researches that have been carried out in various organizations, it has been documented that managers and supervisors who have a high level of self-efficacy, a form of self-confidence, were evaluated as having exemplary job performance. Assessing self-confidence of employees helps to differentiate among high achievers and average workers (Goleman, 2001). According to Okapako.\& Eketu (2016) states that employees in the hospitality industry must be very conscientious oriented people, so that the concept and idea of continuity will have value. On another note, the authors emphasizes that, employees who exhibit conscientiousness in their assignment are likely to be productive because of their zeal to conquer in the midst of toughness.

\subsection{Relationship Management}

According to (Boyatzis, Goleman, \& Rhee, 2000) the main idea behind this theory was to see other employees working towards the goal by developing their skills knowledge and their abilities. Managers can also influence the employees by which getting the work done in a proper way. Strong communication is very much necessary to understand the complete state of the mind of the people and the surroundings. Employees will certainly feel and face the conflict within the senior managers and that comes drives the employees to a distressful state. To some extend the employees become professional leaders and they would at times show poor performance while managing difficult situations. Many managers become a great catalyst and go for a constructive change in their way of dealing the employees and build trust and create bonds with the junior level. It is also seen that teamwork \& collaboration is a part of the managers and employees go hand in hand to get the things done. According to Robert Plutchik (1980) American psychologist has come up with a wheel of emotions that is seen in human nature. He has expressed that people has a basic set of emotions that could be seen in daily life which is inevitable. These emotions are normally seen as the common and basic emotions. The wheel of emotions clearly indicates and relate to the behavior of the people that express and will also help us to improve and change according by reflecting to it. Emotions are seen as reinforcement and energy that is experienced in human mind. The eight sectors of Plutchik's Wheel show the eight primary emotions. Every emotion has a link to each other. Emotions are seen with an intense in reactions and feelings that is expressed out. It can even be an outburst from different colleagues seen in different situations and mood. Getting annoyed is normally seen when one does not like the way of doing or even pestering person. Rage is an intense anger and strong dislike towards a person shown by facial expressions. The white areas show the emotion that is related to the two emotions near it. For example, serenity and acceptance is love. 


\subsection{Managing Emotions In The Workplace}

Managing emotions is the most complex step that exists within emotional intelligence. It involves the ability of knowing how to manage ones 'emotions and being able to adjust feelings in oneself. This is important in situations where one needs to recognize that they have to calm down, control their anger, suppress their disappointment or help someone in pain while easing their own pain (Mayer et al, 2000) Ability to stay open to feelings, both those that are pleasant and those that are unpleasant, ability to reflectively engage or detach from an emotion depending on its judged in formativeness or utility, ability to reflectively monitor emotions in relation to oneself and others, such as recognizing how clear, typical, influential, or reasonable they are, ability to manage emotion in oneself and others by moderating negative emotions and enhancing pleasant ones, without repressing or exaggerating information they may convey" (Gowning, 2001). According to Grewal and Salovey (2006), there is lot of proof and evidence that suggests that the tactics and ability to manage and interpret emotions in an effective way plays an important role in many of lives. The ability to extract and use the emotional intelligence in a perfect way may help one choose a real meaningful line of work and will certainly raise up to the occasion to succeed in life and enjoy work to the fullest potential that can also develop satisfying relationships with colleagues and dear ones. A major study that was conducted by Longhorn (2004) in United Kingdom and seen that emotionally intelligent managers positively affect the financial performance of the company. An emotional intelligent manager can really increase the annual profits of his company by $22 \%$ per year in comparison to the average annual profit growth of $15 \%$ (Bharwaney, Bar-On \& MacKinlay, 2011).

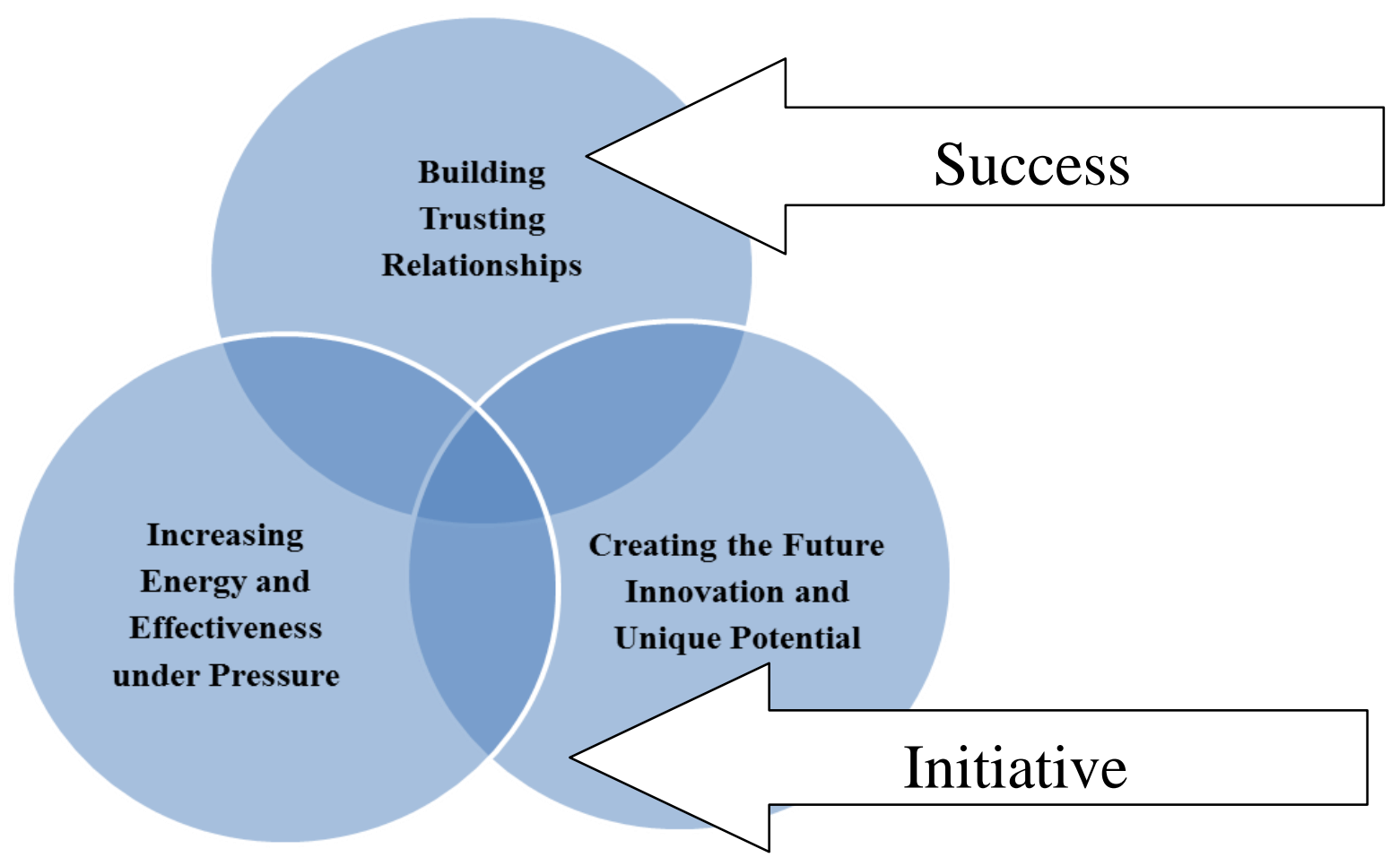

Figure 1; The Q Metrics Approach: An Effective method of Training and Developing of employees to perform better under pressure (Q Metrics. Robert .K.Cooper 1997) 


\section{Ml Macrothink \\ International Journal of Learning and Development \\ ISSN 2164-4063 \\ 2016, Vol. 6, No. 2}

\subsubsection{Increasing Energy and Effectiveness under pressure:}

Increasing energy and effectiveness of an employee under pressure is very important and it's a sheer ability of managing ones energy throughout the daily operations in the organization with the co employees. This is declining when a person is completely under pressure and fails to perform better. Maintaining their energy and increasing the productivity when the employees are under pressure is as exceptional case of close watch by the managers or supervisors. (Cooper 1997)

\subsubsection{Building Trusting Relationship}

Building trust within the organization and within the employees is seen as a cluster that addresses the abilities to trust ourselves. This will lead them to show more sincerity towards the employees and to the management that creates a positive working environment that shows a clear relation internally and externally. Their abilities will also direct them to enhance interactions with the clients, customers and teams. This will also save lots of time and help each other to get things to better shape and more meaningful to the organization and to the team member's itself. (Cooper 1997)

\subsubsection{Creating the Future Innovation and Unique Potential}

Creating the future deals with the ability of dealing the team internally and externally shows beyond the conventional, that come up with unorthodox solutions and serve member's, clients and others life and show true and substantial results. Creating the future developments are also identified has promising opportunities for personal and professional development. The cluster stabilizes and dominates on the individual's unique potential - core talents and potential strengths of the employees. These also push the company or the managers to see the ability and recognize their individual and team skills that help them to activate in a proper way. (Cooper 1997)

\section{Methodology}

The empirical research is tested in Tamilnadu among the employees of hospitality industry. The study is explorative in nature as it attempts to explore the relationship and impact of Q metric approach on training for emotional intelligence competence. The population size i.e., the employees of hospitality industry is unknown so nonprobability sampling technique has been adapted to test. As proposed by Hair et al (1998), the minimum sample to have at least five times as many observations as there are variables to be analyzed, and the more acceptable size would be a ten-to-one ratio. As proposed by C.R.Kothari, the pilot study can be used to determine the number of samples necessary for the main study. The number of employees was surveyed for this research is 180. A model was developed by using analysis of moment structure (AMOS). A model is fit to ensure the model for Q metric approach in the training of Emotional intelligence competence among the employees of the hospitality industry, Tamil Nadu -India. 


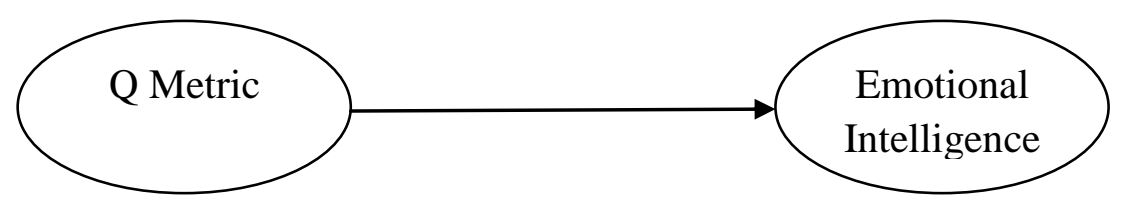

Figure 2: Research Frame work: The effect of Q metric approach in the training of emotional intelligence competence

\section{Findings and Discussions}

In this model, independent variables such as Building Trusting Relationship (BTR), Creating the Future Innovation and Unique Potential (CFI), Increasing Energy and Effectiveness under pressure (IEE) are taken as observed variables through which second order factor (unobserved variable) Q metric approach was formulated. Emotional intelligence competence is second order factor which is measured through the four dimensions Self-Awareness (SA), Social Awareness (SoA), Relationship Management (RM), Self-Management(SM) is taken as observed variable. e1, e2, e3, e4, e5, e6, e7, are error terms (residuals) for independent variables and $\mathrm{e} 8$ is error term for dependent variable.

Null Hypothesis $\mathbf{H}_{\mathbf{0}}$ : The model fitted for Q metric approach in the training of Emotional intelligence competence is good.

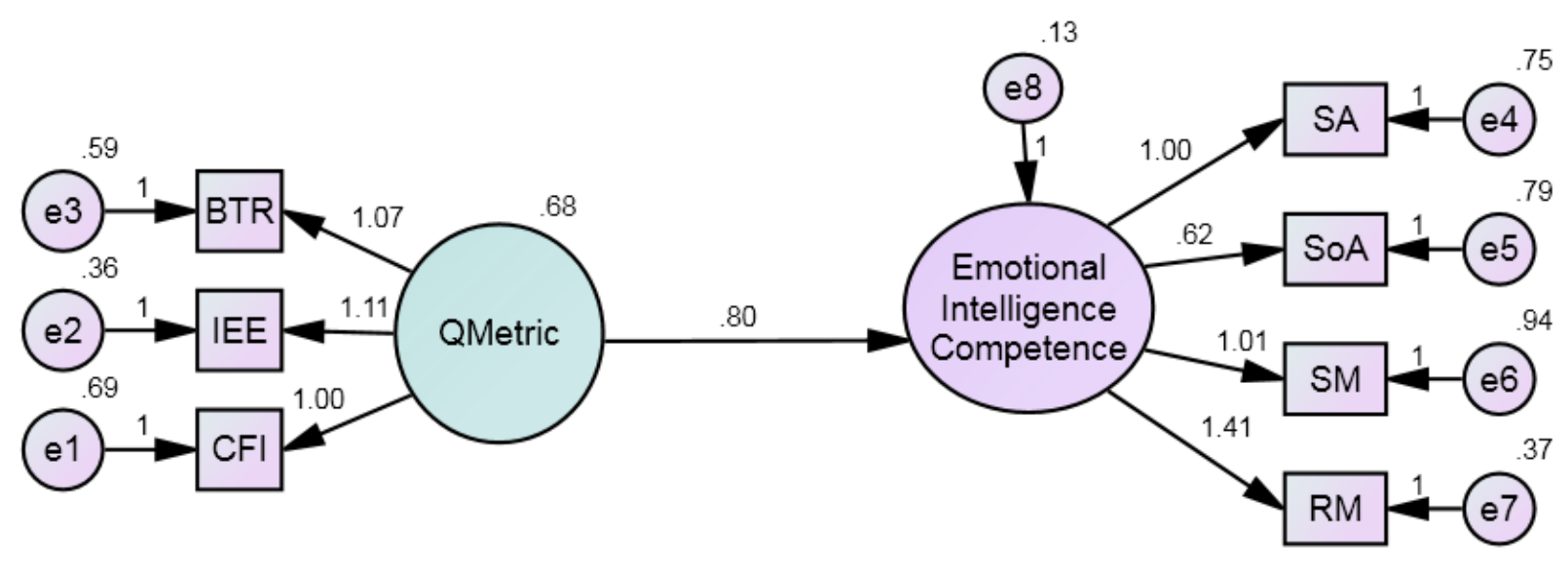

Figure3. The effect of Q metric approach in the training of emotional intelligence competence

\subsection{Model fit Summary}

The model fit Chi-square $\chi^{2}=12.059$ and the model's p-value is 0.523 which is insignificant at 5\% level, which shows that the null hypothesis "The role of $\mathrm{Q}$ metric approach in the training of emotional intelligence competence is good" is accepted. The goodness of fit index (GFI) is 0.958 of the model, shows reasonably good fit, and its adjusted goodness of fit (AGFI) is 0.908. The Root Mean Square Error of Approximation (RMSEA) is 0.04 and RMR is 0.049 , a smaller value indicates better model, which are within the acceptable range indicating a better model fit. 


\section{Macrothink}

The hypothesized research model exhibited good fit with observed data as mentioned above. The regression value (.80) denotes that the impact of Q metric on the emotional intelligence competence and the path estimates in the structural model and variance explained (.68). The hypothesized path is significant (.000). So the null hypothesis is accepted as the model fitted for Q metric approach in the training of Emotional intelligence competence is good. It is understood from the results of the structural equation modeling that $\mathrm{Q}$ metric is measured through BTR, IEE and CFI the variance of which is well explained above $50 \%$ except IEE variance of which is explained only $36 \%$. On the other hand, Emotional intelligence competence's variance is well explained above $70 \%$ except RM of which the variance explained is only $37 \%$. On the whole, the Q metric has an impact on emotional intelligence competence. From this study, the researcher would recommend the hospitality employers to adapt the Q metric approach in their emotional intelligence competence development so that the employees can be more emotionally stable and they can serve better in all aspects.

\section{Conclusion}

It has been observed that training in the hospitality industry becomes a challenge as the employees in this industry have been significantly increased in recent years. Employees are trained to perform well in the organizations while they are also paid to perform in a specific department. It's the combination of experience, calibre, knowledge, skills and abilities that pushes you forward to the particular position to perform in any organization. This study was initiated with a view to understand the relationship and the impact of Q metric on emotional intelligence competence. It is understood by the researcher that $\mathrm{Q}$ metric approach in the training of Emotional intelligence competence makes some better results as far as the emotions and developments of the employees in hospitality industry.

\section{Acknowledgement}

We would like to take this opportunity to thank our Prof. Dr. B. Rajasekeran, Professor \& Head, Department of Management Studies, Manomaniam Sundaranar University, Tamil Nadu, India for guiding and supporting us in this research work.

\section{References}

Akduman .G. Hatipoğlu .Z \& Yüksekbilgili .Z. (2015) A Research about Emotional Intelligence on Generations .International Journal of Advanced Multidisciplinary Research and Review Volume 3, No.4,ISSN 2330-120.

Bar-On, R. (2006). The Bar-On model of emotional-social intelligence (ESI). Psicothema, 18, supl. 13-25.

Boyatzis, R., Goleman, D., and Rhee, K. (2000). Clustering competence in emotional intelligence: Insights from the emotional competence inventory (ECI). In R. Bar-On and J.D.A. Parker (Eds.), Handbook of emotional intelligence. San Francisco: Jossey-Bass.

Bharwaney, G., Bar-On, R., \& MacKinlay, A. (2011). EQ and the Bottom Line: Emotional Intelligence increases individual occupational performance, leadership and organisational productivity. 


\section{Macrothink}

International Journal of Learning and Development

ISSN 2164-4063

2016, Vol. 6, No. 2

Cherniss, C. (1999). The business case for emotional intelligence. Consortium for research on emotional intelligence in organizations.

Cherniss, C. (Composer). (1998). The optimal process for developing emotional intelligence in organizations.

Cherniss, C., \& Goleman, D. (Eds.). (2001). Measurement of Individual Emotional Competence. In The Emotionally Intelligent Workplace. (1st ed.). (p. 94). San Francisco, United States of America: Jossey-Bass.

Cherniss, C., Goleman, D., Emmerling, R., Cowan, K., \& Adler, M. (1998). Bringing emotional intelligence to the workplace: A technical report issued by the consortium for research on emotional intelligence in organizations.

Cooper. R (1997) Q- Metrics Emotional intelligence in leadership and organizations EQ Map

Emerald Group Publishing. (Photographer). Bar-on eq-i descriptions. [Web Photo]. Retrieved from http://www.emeraldinsight.com/content_images/fig/0370350501001.png

Deshwa. P (2016) Impact of Emotional Intelligence on Organizational Performance. International Journal of Advanced Research in Management and Social Sciences. ISSN: 2278-6236. Vol. 5 | No. 1. IJARMSS

Emmerling, R. (2012). About the consortium for research on emotional intelligence in organizations. Retrieved from http://www.eiconsortium.org/about_us.htm

Goleman, D. (1995). Emotional Intelligence: Why it can matter more than IQ. New York: Bantam.

Goleman, D. (2001). Emotional intelligence: Issues in paradigm building. In C. Cherniss and D. Goleman (Ed's.), The Emotionally Intelligence Workplace. San Francisco: Jossey-Bass.

Gardner.H (1993) Frames of Mind: Theory of multiple intelligences. Fontana Press,

L. L. Thurstone. The nature of intelligence. Routledge, London, 1924.

Gowing, M. K. (2001). Measurement of individual emotional competence. In C. Cherniss, \& D. Goleman (Eds.), The emotionally intelligent workplace: How to select for, measure, and improve emotional intelligence in individuals, groups, and organizations (pp. 83-131). San Francisco, CA: Jossey-Bass.

Grewal, D. D., \& Salovey, P. (2006). Benefits of emotional intelligence. In M. Csíkszentmihályi \& I. S. Csikszentmihalyi (Eds.), A life worth living: Contributions to positive psychology. (1st ed.). (p. 104). New York, United States of America: Oxford University Press.

Hair, J.F., \& Anderson, R.E., Tatham, R.L., \& Black, W.C. (1998). Multivariate data analysis (5th ed.). Englewood Cliffs, NJ: Prentice Hall. 


\section{Macrothink}

International Journal of Learning and Development

ISSN 2164-4063

2016, Vol. 6, No. 2

Kothari.C.R (2004) Research Methodology, Methods and Techniques. New Age International (P) Limited, Publishers, ISBN:978-81-224-1522-3

Kumari .S (2016 ) Emotional Intelligence (Ei) And Sport Science: A Systematic Study Of Need, Importance And Application Of Emotional Intelligence In Athletics. International Journal of Advanced Research. Volume 4, Issue 1, ISSN 2320-5407. http://www.journalijar.com. Retrieved on $2^{\text {nd }}$ June 2016.

Longhorn, S. (2004),"How emotional intelligencecan improve management performance",

International Journal of Contemporary Hospitality Management.

Mayer, J. D., Salovey, P., \& Caruso, D. (2000). Models of emotional intelligence. In R. Sternberg (Ed.), Handbook of intelligence. (1st ed.). (pp. 396-420). Cambridge, UK: Cambridge University Press.

Mayer \& Salovey's (1997) four branch model of ei. [Web Photo]. Retrieved from http://www.education.com/reference/article/emotional-intelligence1/ Gale Group. (Producer). (2009).

Okapako.O.I \& Eketu . C.A ( 2016) Emotional Intelligence and Workers' Conscientiousness in selected hotels in port harcourt . International Journal of Advanced Academic Research Social \& Management Sciences ISSN: 2488-9849 Vol. 2, Issue 5. www.ijaar.org

Plutchik, R (1980) Wheel of Emotions: A Psych evolutionary synthesis. New York: Harper \&Row

R. J. Sternberg. An interview with Dr. Sternberg. In J. A. Plucker, editor, Human intelligence: Historical influences, current controversies, teaching resources. http://www.indiana.edu/_intell, 2003.

Taylor, G.J., Parker, J.D.A., and Bagby, R.M. (1999). Emotional intelligence and the emotional brain: Points of convergence and implications for psychoanalysis. Journal of the American Academy of Psychoanalysis, 27(3), 339-354.

\section{Glossary}

BTR - Building Trusting Relationship

CFI - Creating the Future Innovation and Unique Potential

EI- Emotional Intelligence

IEE - Increasing Energy and Effectiveness under pressure

SA - Self-Awareness

SoA - Social Awareness

RM -Relationship Management

SM - Self-Management 


\section{Macrothink}

\section{Copyright Disclaimer}

Copyright for this article is retained by the author(s), with first publication rights granted to the journal.

This is an open-access article distributed under the terms and conditions of the Creative Commons Attribution license (http://creativecommons.org/licenses/by/3.0/). 